\title{
Hazard Analysis of Sate Bandeng as Indigenous Food From Banten
}

\author{
*Dian Anggraeni \\ Agribussiness Department \\ University of Sultan Ageng \\ Tirtayasa \\ Serang, \\ Indonesia Indonesia Center of \\ Execelenc for Food Security \\ (I-CEFORY), UNTIRTA \\ (Local Food Innovation) \\ *dian.1452@yahoo.co.id
}

\author{
Zulfatun Najah \\ Food Technology Department \\ University of Sultan Ageng \\ Tirtayasa \\ Serang, Indonesia \\ z.najah@untirta.ac.id
}

\author{
Winda Nurtiana \\ Food Technology Department \\ University of Sultan Ageng \\ Tirtayasa \\ Serang, Indonesia \\ winda@untirta.ac.id
}

\author{
Nia Ariani Putri \\ Food Technology Department \\ University of Sultan Ageng \\ Tirtayasa \\ Serang, Indonesia) \\ nia.ariani@untirta.ac.id
}

\begin{abstract}
Sate bandeng is indigenous food from Banten Province and produced by SMEs (small and medium enterprises). The market of sate bandeng is not yet wide because it has short shelf life about two days only. The short shelf life of sate bandeng because it is made from coconut milk and their standard processing method is not good yet. The quality standard of processing sate bandeng in SMEs can be improved through implementation of quality assurance. The quality assurance was applied by identification of hazards, assessing of the risks, and control of hazard. The aim of this study was to mapping of production processing, to analyze hazards on onsate bandeng and to design the improved of production. The research method was conducted by interview, observation, laboratory analysis, andliterature review. Laboratory analyzeon all hazards consist of chemical, physical, and microbiological hazard. Based on observation.the production processes of sate bandeng are washing, separation, mixing, refilling, clamping, and grilling. The hazards on sate bandeng are dust, fish bone, lead, cadmium, E.coli and Staphylococcus.
\end{abstract}

\section{Keywords: Hazard, Sate Bandeng, SME, Quality}

\section{INTRODUCTION}

Fishery and agriculture is basic sector of Banten Province. One of featured fishery product of Banten Province is milkfish. Milkfish is a favourite of many peoplebecause it contains high nutritional value and complete acid amino which is good for health, also the price is cheap [21]. Even though it contains quite high protein,milkfish also has a weakness that is fish flesh smelling mud and there are many smooth fish bone that are not easy to removed, so it is not practice to consume. Beside, milkfish is one of perishable food because of the spoilage microbe is very easy to grow [10]. To extend the shelf life and improve the practice of consume, then the milkfish processing is carried out. One of the milkfish processed product is sate bandeng.

Sate bandeng is indigenous product from Banten Province especially Serang. The producer of sate bandeng is concentrated atSerang City $(64 \%)$ and Serang Regency $(36 \%)$. All of this producer is small medium enterprises (SME) with two until five workers [25]. Sate bandeng contains of high nutritional value like protein $(20 \%)$, fat $(0.72 \%)$, mineral $(28.12 \%)$, carbohydrate $(0.114 \%)$, and water $(75.85 \%)$ [10]. The specialty of sate bandengthan other milkfish processed products is the making like other satay, meat and bones are separated which makes it easier to consume and has a distinctive taste of grilled food [25].

Although sate bandeng has become a typical and special food of Banten, sate bandengmarketing can not yet wide even though the demand from outside Banten is very much. This is because the shelf life is only about two days. Short shelf life is caused by the processing that use of coconut milk as one of main material and production methods that have not followed the standard, like not implementing sanitation and hygiene in the production process. This non-standard production method causessate bandengis very potential to has the hazards. The hazards are physical, chemical, and microbiological, all of this hazards can reduce the quality and shelf life of sate bandeng. Food safety assurance in sate bandeng is a solution to anticipate the hazard, so that does not pose a risk of health when it is consumed.The aim of this study was to analyze hazards on sate bandeng and to design the improved of production .

\section{RESEACH DESIGN}

\section{A. Study area}

This study was performed in sate bandeng SMEs (small medium enterpraise) located in Serang city, Banten. There are 17 SMEs of sate bandeng in Serang City. The SME sate bandeng selection asa sample was done by purposive sampling. It is because Serang is center of sate bandeng. SMEs was choosen based on production capacity and technology application. The tradional and modern SMEs was chosen as comparison. The researchers spent 3 month from june until August 2019 in order to observe all the to final product, the process production and monitor quality controlin order to improvethequality of satebandeng.

This research was designed into three step include analyzed of production process, analyzed of hazard and design recommendation forproduction improvement. Sate bandeng processing was mapped using flowchart diagram. This processing data were collected by direct observation and intervewing the owner. The in-depth interview consists production processing and SME management practice.Hazard analysis consist of physical, chemical, and biological hazard analysis. This hazard were analyzed by laboratory experimental. Direct observationof processing was used for physical hazard analysis. Laboratoryanalysis 
was used for chemical and biological contamination in food (Satay).

\section{B. Methode}

Physical hazards include foreign objects in food that can cause harm when eaten, such as glass or metal fragments. Biological hazards include harmful bacteria, viruses or parasites (e.g.,salmonella, hepatitis A and trichinella). Chemical hazards include compounds that can cause illness or injury due to immediate or long-term exposure. Hazard analysis in sate bandeng was done for physical, chemical, and biological hazard. Chemical hazard in the sate bandengmetal analysis of $\mathrm{Pb}$ and $\mathrm{Cd}$. This contaminant was measure by AAS (Atomic absorption spectroscopy). The microbilogical contamination was measured by ALT [17], and [14], Escherichia coli [4], Salmonella sp [15], Vibrio cholerae[16], Vibrio parahaemoliticus[16]. The physical analysis was done by visualization analysis by researchers.

\section{Material and Tools}

The sample were satebandeng from 2 SMEs. The first sate bandeng getting from SME that used traditional processing practices $(\mathrm{X})$, and the second sate bandneg getting from SME used modern practices/using mincing machine in the processing technics (Y).

\section{PRODUCTION SATE BANDENG}

Sate bandeng production was carried by several steps: washing, removing of scales, organs, and fishbones, filleting, mincing, mixing, grilling, and packaging. Flow chart sate bandeng production can be seen on Figure 1. On this process, grilling were carrried twice. First,refilling fish batter into the fish skin and grilling. On this process, fish skin was grilled half-cooked. The second grilled was carried aftercoating fish batter into the half cooked-fish skin. The grilled processed was done until it become fully grilled (sate bandeng). Finally, sate bandeng was packed by vacuum package (SME $\mathrm{Y}$ ) or banana leaf (SME X) and carton.

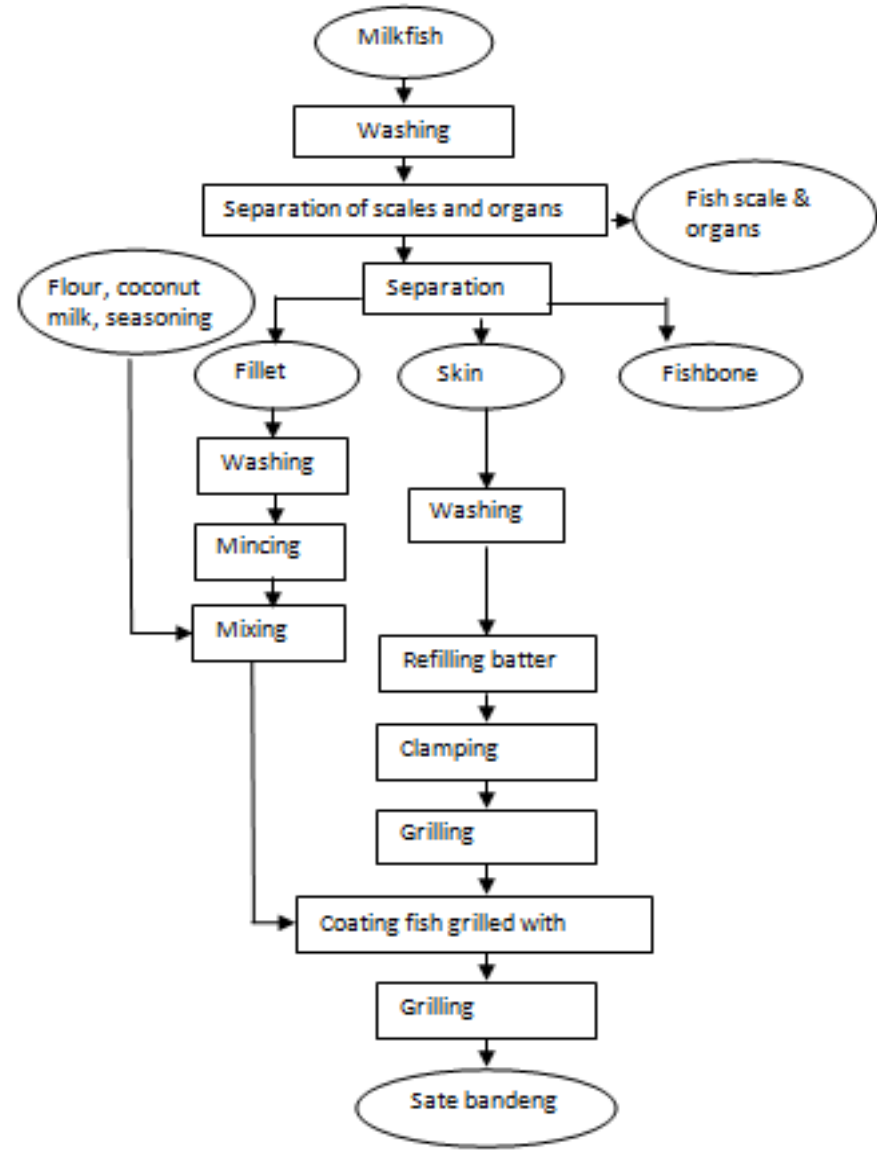

Fig. 1. Flowchart of Sate Bandeng Production

\section{RESULT AND DISCUSSION}

Feasible food for consumption is food that is not rotten, not disgusting, and have a good quality, and free from three contaminants.As food, sate bandeng's production needs to pay attention to the food safety.Food safety is the condition and effort to prevent food from possible contaminations, namely physical, biological, chemical, and other objects that can disturb, detrimental, and endanger human health and does not conflict with the religion, beliefs and culture of the people so that it is safe for consumption.Food safety hazard means any biological, chemical, or physical property that may cause a food to be unsafe for human consumption and human health. Unsafe food can be minimize by implementation of Good Manufacturing Practices (GMP). So that, food processing must be based on GMP to prevent hazards.

\subsection{Hazard Analysis}

Ahazard analysis in the fisheries product was carried out to determine whether there are food safety hazards that are reasonably likely to occur for each kind of fish and fishery product and to identify the preventive measures that the processor can apply to control those hazards[22].

\section{A. Physical hazard analysis}

The physical hazards occur because of raw material and processing.Physical hazards can be defined as hard, sharp foreign objects that are not expected to be present in the food product and may be intrinsic or extrinsic [5].Physical hazard 
insate bandeng can bedust, gravel, hair, ash, and fish bone.Fish skin, fish scale, or fishbone can be regarded as hazard [26]. Dust in the sate bandeng result of bad sanitation or enviroment. Gravel result of bad grilling processing. The hair result of bad personal sanitation (worker doesn't wear production uniform). Fishbone result of unminced fish because SME still used traditional processing practices. For almost SME, The physical contaminationare because of the environment, containers and transportation equipment, equipment or processing unit [26].

Physical hazards may cause injuries in the mouth, teeth, pharynx and/or throat or can lead to asphyxiation in a worstcase scenario[5].But, some foreign material in food products may not be a physical hazard but rather an undesirable foreign material such as hair, insects, or sand that are not likely to cause injuries. The physical hazard classified into two class. Intrinsic physical hazards may be 'naturally' present in the food, but are not expected in processed food. Extrinsic physical hazards are usually a contamination from the production environment [11]. Table 1 represent the classification of physical hazard.

TABLE I. TABLE CLASSIFICATION OF PHYSICAL HAZARD

\begin{tabular}{|l|l|}
\hline \multicolumn{1}{|c|}{ Type of hazard } & \multicolumn{1}{|c|}{ Meaning } \\
\hline Intrinsic hazards & $\begin{array}{l}\text { Fish and meat bones/bone fragments, fruit stones } \\
\text { (olives, peaches, etc.) }\end{array}$ \\
\hline $\begin{array}{l}\text { Extrinsic } \\
\text { hazards }\end{array}$ & $\begin{array}{l}\text { Hard plastic or metal from production and } \\
\text { measuring equipment, glass from lighting in } \\
\text { production areas, wooden splinters from pallets, etc. }\end{array}$ \\
\hline Refering to [2]
\end{tabular}

Physical hazard in food must be negative. But in practice, there are still physical hazards in sate bandeng. The physical hazard found in the SME Xcan be ash, dust and fishbone. The physical hazard in the SME Y can be fishbone. The SME X still used traditional methode processing and some workers work unproperly. Some hygiene practices have not been carried out by worker in the processing unit include the use of work clothes, masks, washed their hands before and after processing, did not eat, spit, sneeze, and did not smoke while doing production[24]. The SME Y has implemented good production methods such as use clothes sanitation properly, wash their hand, and did not smoke while doing a job. So that, the physical hazard minimial. The sate bandeng processing can eliminate physical hazard. This proves that the sate bandeng production process needs to be improved.

\section{B. Chemical hazard analysis}

Milkfish (Chanoschanos) is aquatic product that can be contaminated by heavy metals. Heavy metals which are hazardous and toxic materials in the waters can come from land activities around these waters like industrial activities, oil mining, agriculture, transportation, hospitals, and any other domestic activities[7]. Waste containing heavy metals without prior treatment can have a negative impact on aquatic ecosystems [7]. Heavy metals will contaminate sea water and surrounding waters so it will accumulate in the bodies of aquatic living things [8]. Beside from the waters where they live, heavy metal contamination in fish can be influenced by various things such as the age of the fish, fat content in the tissue, and how to eat[9].

Milkfish can be contaminated with lead and cadmium metals when using aquaculture water sources from polluted waters. If milkfish as raw material is contaminated bylead and cadmium, then sate bandeng as its processed also will be contaminated. The following results of lead and cadmiumanalysis on sate bandeng can be seen on Table 2

TABLE II. TABLE ANALYSIS OF LEAD AND CADMIUM ON SATE BANDENG.

\begin{tabular}{|c|c|c|c|}
\hline $\begin{array}{c}\text { Heavy Metal } \\
\text { Hazard }\end{array}$ & $\begin{array}{c}\text { Sate } \\
\text { Bandeng "X' }\end{array}$ & $\begin{array}{c}\text { Sate } \\
\text { Bandeng } \\
\text { "Y" }\end{array}$ & $\begin{array}{c}\text { NADFC } \\
\text { Standard }\end{array}$ \\
\hline $\mathrm{Pb}(\mathrm{Lead})$ & $0.14 \mathrm{mg} / \mathrm{kg}$ & $0.18 \mathrm{mg} / \mathrm{kg}$ & $0.20 \mathrm{mg} / \mathrm{kg}$ \\
\hline $\mathrm{Cd}(\mathrm{Cadmium})$ & $<0.007 \mathrm{mg} / \mathrm{kg}$ & $<0.007 \mathrm{mg} / \mathrm{kg}$ & $0.10 \mathrm{mg} / \mathrm{kg}$ \\
\hline
\end{tabular}

Refering to [19], [20]

Table 2 shows that the lead and cadmium content on both of sate bandeng are still below the NADFC standard, so it is still safe for consumption.However, the content of lead onsatebandeng " $\mathrm{Y}$ " is almost close to the standard limit. The source of milkfish as raw material for makingsatebandeng "Y" comes from the wholesale market in Serang City. The traders get milkfish from the aquaculture around the area near the waters of the Banten Bay (northern of Serang City). Lots of industrial activities that exist around the Banten Bay likes PT. Samudera Marine Ship Yard, PT. Krakatau Steel, PT. Angel Situ TasikArdi, andSugar Factory ofBojonegara[3].Beside that, there are ship loading and unloading activities that also contribute to lead contamination [3]. Therefore, it is possible that the lead contamination of sate bandeng" $Y$ " comes from the raw material.Meanwhile, the source of milkfish in the processing ofsate bandeng " $\mathrm{X}$ " comes from farmers in the Karawang and Subang areas. Different types of waters cause different lead concentrations in sate bandeng as final product.

Lead has high toxicity to humans and can damage brain development in children, cause red blood cell blockage, anemia, and affect other limbs [3]. Therefore it is very important to know the lead contamination in consumed fishery products.

The results of the cadmium analysis on both of sate bandeng showed that the concentration was below the NADFC standard. The low cadmium content is possible because the waters of the milkfish aquaculture have not been contaminated with very large amounts of cadmium metal.Chronic cadmium poisoning causes the damage ofthe urinary system (kidneys), respiration (breathing/lungs), blood circulation and heart, damage the reproductive glands, the olfactory system, and bone fragility [2].

Lead and cadmium can enter the milkfish body because the water in which they live is contaminated by heavy metals.Heavy metals that have been dissolved in water are more bioavailable, so it will be easier to enter the fish's body. Furthermore, heavy metals will enter the body through the gills and skin, or through the food and settles on the body [7].

The sate bandeng processing cannot eliminate lead or cadmium contamination, because when processing ofsatebandeng there is no addition of organic materials. Metals can bond with natural organic material and artificial organic material[12]. The process of forming these bonds 
can occur through the formation of organic salts with carboxyl groups likes citric acid, tartrate acid, etc. Beside that, metals can bind to atoms which have free electrons in organic compounds to form complexes [18]. The thing that must be considered to avoid heavy metal contamination in sate bandeng is the selection of appropriate raw materials for sate bandeng,must come from waters that are not contaminated by heavy metals.

\section{Biological hazard analysis}

Foodborne disease means disease that arise because of consuming food that have material, toxic material, or are contaminated pathogen organism/ unsafe food[1]. Total and variety of microorganism population on several fisheries products are very specific [13].Microorganism on fisheries products are from several sources, for example: soil, surface water, dust, digestive tracts of humans and animal, environment of cultivation, preparation, storage and processing. Microbiological criteria are measures of risk managementwhich shows the acceptance of a food orthe performance of a food safety process or systemic the result of sampling and testingmicrobes, toxins or their metabolites or markers that arerelated to pathogenicity or other propertiesat a certain point in a food chain [19].

Microbiological criteria that has been measured are total plate count (TPC), Escherichia coli (E. Coli), Salmonella sp., Vibrio cholerae, and Vibrio parahaemolyticus. The result of biologcal hazard onsate bandeng can be seen on Table 2.TPC result of sate bandeng $\mathrm{Y}$ is higher than sate bandeng $\mathrm{X}$. Based on [19] (Table 3.), TPC that can be toleranted is $10^{4}$ colony/g (Table 4). It means, total microorganism on $\mathrm{Y}$ product is higher than $\mathrm{X}$ product. Microorganism were observed on TPC still not identified for pathogen or non pathogen microorganism. The next observation, showed that both of them were found $E$. coli.

TABLE III. TABEL MICROBIOLOGICAL CRITERIA RESULT OF SATE BANDENG

\begin{tabular}{|c|c|c|}
\hline Microbiological Criteria & $\mathrm{X}$ & $\mathrm{Y}$ \\
\hline TPC $($ colony/g) & 50 & $8,2 \times 10^{4}$ \\
\hline E. coli $(\mathrm{APM} / \mathrm{g})$ & $<3$ & $<3$ \\
\hline Salmonella $\mathrm{sp}$. $(/ 25 \mathrm{~g})$ & Negative & Negative \\
\hline Vibrio cholerae $(/ 25 \mathrm{~g})$ & Negative & Negative \\
\hline Vibrio parahaemolyticus $(/ 25 \mathrm{~g})$ & Negative & Negative \\
\hline
\end{tabular}

Fisheries products that have a high microbiological hazard causes a foodborne disease if humans consume it. Reference [6] was said that E. coli causes diarrhea by producing a type of poison called enterotoxin. Salmonella sp., Vibrio chlorae, and Vibrio parahaemolyticuswere not found on both products based on laboratory analysis result.The three microorganism doesn't exist on both products. Salmonella $s p$ emerges from humans and animals feaces.It is very infective, less than 100 cells cause disease [17].
TABLE IV. TABLE MICROBIOLOGICAL CRITERIA RESULT OF SATE BANDENG

\begin{tabular}{|c|c|c|}
\hline Microbiological Criteria & M & M \\
\hline TPC (colony/g) & $10^{4}$ & $10^{5}$ \\
\hline $\begin{array}{c}\text { Staphylococcus aureus } \\
\text { (colony/g) }\end{array}$ & $10^{2}$ & $10^{3}$ \\
\hline
\end{tabular}

Refering to[17]

Note:m, M = microorganisme boundary

\section{CONCLUSION}

The physical hazard in the sate bandeng can be dust, ash, gravel orhair. The foreign material from sate bandeng that must be remove is fishbone. But this material stil on the both sample. The biological hazard identified in the sample was TPC and E. Coli. TPC can be toleranted in the food is 104colony/g. The both sample stillsafe for consumption because the microbial content still below the standard acoording to NADFC. The chemical hazard identified from sample was lead $(\mathrm{Pb})$ and Cadminium $(\mathrm{Cd})$. The lead and cadmium content on both of sate bandeng are still below the standard, so it is still safe for consumption.

\section{ACKNOWLEDGMENT}

We would like to express a special gratitude to Islamic Development Banks, whose funding this research.

\section{REFERENCES}

[1] A. Faisal, Book of Food and Nutrition Introduction, Jakarta (ID): Swadaya (in Indonesia), 2002.

[2] A. Purnomo, R. Purwana, "Impact of Cadmium in Fish on Public Health”, (In Indonesia), Jurnal Kesehatan Masyarakat Nasional, vol 3, no 2, pp. 89-96, 2008.

[3] A.N. Putri, "Distribution Spatial of Lead Heavy Metal in Banten Bay," B.Sc Theses. FakultasPerikanandanIlmuKelautan, IPB University, Bogor, (In Indonesia), 2012.

[4] Bacteriological Analytical Manual Chapter 4ADiarrheagenic Escherichia coli, Food Drugs Association. 2002.

[5] Biohaz, "Hazard Analysis Approaches For Certain Small Retail Establishments In View Of The Application Of Their Food Safety Management Systems Efsa Panel On Biological Hazards,"EFSA Journal, vol 15, no.3, pp.1-52, 2017.

[6] E. Jawetz, Medical Microbiology, (In Indonesia), Jakarta (ID): Salemba Medika. 2001.

[7] E. Riani, Climate Change and Life of Aquatic Biota (Bioaccumulation of Hazardous and Toxic and Reproductive Materials), (In Indonesia), Bogor (ID) : IPB Press, 2012.

[8] E. Riani, H.S. Johari, M.R. Cordova, "Contamination of Cd andPb on Milkfish (Chanoschanos) Cultured In Seribu Islands, Jakarta," Jurnal Ilmu dan Teknologi Kelautan Tropis, vol. 9, no.1,pp. 235-246, 2017.

[9] F. Asante, E. Agbeko, G. Addae, and A.K. Quainoo, "Bioaccumulation heavy metals in water, sediments and tissues of some selected fishes from the red volat, Nangodi in the Upper East Region of Ghana," British J. Appl. Sciand Technol, vol 4, no.4, pp.594-603, 2012.

[10] Hafiludin, "Analysis of Nutrition Content in Milkfish Originating from Different Habitats," (IN Indonesia), Jurnal Kelautan, vol 8, no.1, pp. 37-43, 2015.

[11] H. Lelieveld, M. Mostert, J. Holah, and B. White, Hygiene in Food Processing”, Boca Raton, USA: CRC Press, pISBN 0-8493-1212-4, 2003, pp. 392.

[12] H. Palar, Pollution and Toxicoloy of heavy Metal, (In Indonesia), Jakarta (ID) : RenikaCipta, 2008.

[13] Marpaung, Ridawati,"Microbiology Study on Dried Salted Fish in Traditional Market and Supermarket to Increase Food Safety in Jambi City", (In Indonesia), Jurnal Ilmiah Universitas Batanghari,vol. 15, no 3, 2015 . 
[14] Microbiology of Food and Animal Feeding Stuff - General Requiement and Guidance For Microbiological Examination". ISO No. 7218International Standard Organization, 2012.

[15] Microbiology of Food and Animal Feeding Stuffs- Horizontal Method For The Detection of Salmonella Spp, ISO No 6579, International Standard Organization,2002.

[16] Microbiology Of Food And Animal Feeding Stuffs -- Horizontal Method For The Detection Of Potentially Enteropathogenic Vibrio Spp. -- Part 1: Detection of Vibrio parahaemolyticus and Vibrio cholera, ISO No 21872-1, International Standard Organization,2007.

[17] Microbiology of Food and Animal Feeding Stuffs - Horizontal Method For The Enumeration of Microorganisms -- Colony-Count Technique At 30 Degrees C, ISO No.4833, International Standard Organization,2003.

[18] M.R. Saputri, F. Rachmadiarti, Raharjo, "Reduction of Lead (Pb) Content on Tilapia (Oreochromisnilotica) in Kali Surabaya by Using Filtrate Siam Orange (Citrus nobilis)", (In Indonesia),LenteraBio, vol 4, no.2, pp. 136-142, 2015.

[19] NADFC [National Agency of Drug and Food Control], Berita Negara Republik Indonesia Tahun 2016 Nomor 1139 (2016,8,4). Peraturan Kepala Badan Pengawasan Obat dan Makanan Republik Indonesia No. 16 2016, Kriteria Mikrobiologi Dalam Pangan Olahan. [Online]. Available atjdih.pom.go.id

[20] NADFC[National Agency of Drug and Food Control], Berita Negara Republik Indonesia Tahun 2017 No 1712 (2017,11,23). Peraturan
Kepala Badan Pengawasan Obat dan Makanan Republik Indonesia No. 23 Tahun 2017, Batas Maksimum Cemaran LogamBeratdalamPanganOlahan. [Online]. Available atjdih.pom.go.id

[21] Pamijiati, "Effect of Basil Leaf Extract (Ocimum basilicum linn) on The Quality of Milkfish Freshness During Cold Storage (Chanos chanos Forsk),",B.Sc Theses, Universitas Diponegoro, Semarang, (in Indonesia) 2019.

[22] Procedures For Safe And Sanitary Processing And Importing of Fish And Fishery Products, Apendix 8, Food Drugs Association, 2019.

[23] S. Hasibuan, and F.S. Mumpuni, "Microbial Prevalence on Pindang Cob - SME Scale in Ratu Port, Sukabumi," (In Indonesia), JPHPI, vol. 21, no. 3, 2018.

[24] T. Hidayat, Z.Najah, N.A. Putri, Zulmaneri, "The Evaluation of Good Manufacturing Practices (GMP) In Fish Processing SME Center Case Study of Balikpapan City,” Food Scientech J., vol.1, no.1, 2019. Inpress.

[25] Wibowo, R. Isna, and Z. Irawati "Study of Technoeconomy Sate Bandeng Produce From Batan RnD," (In Indonesia),Teknoekonomi,ISSN 1978-2918, 2018.

[26] Z.Najah, N.A. Putri, T. Hidayat, Zulmaneri, "A Review Of Hazard Analysis And Critical Control Points Implementation In Amplang Processing," Food Scientech J., vol.1, no.1, 2019. Inpress. 